\title{
Multidrug-resistant Bacterial Profile and Patterns for Wound Infections in Nongovernmental Hospitals of Jordan
}

\author{
Hashem A. Abu-Harirah ${ }^{1 *}$ (D) Audai Jamal Al Qudah² (D) Emad Daabes ${ }^{3}$ (D), \\ Kawther Faisal Amawi ${ }^{1}$ (D) and Haitham Qaralleh ${ }^{4}$ (D) \\ ${ }^{1}$ Faculty of Allied Medical Sciences, Zarqa University, Jordan. \\ ${ }^{2}$ Laboratory Department, Jordan Islamic Hospital, Jordan. \\ ${ }^{3}$ Laboratory Department, Israa Hospital, Jordan. \\ ${ }^{4}$ Department of Medical Laboratory Sciences, Mutah University, Karak, Jordan.
}

\begin{abstract}
Globally, multidrug-resistant bacteria affects wound infections, both hospital-acquired infections and community-acquired infections. The main isolates cultured from 607 subjects with wound infections were methicillin-resistant Staphylococcus aureus (MRSA), Escherichia coli, Pseudomonas aeruginosa, and Acinetobacter spp. [multidrug resistant (MDR)]. Gram-negative bacteria caused most of the infections (67\%) compared with gram-positive bacteria. Diabetic patients tend to have wound infections with mixed causative agents compared with non-diabetic patients.

Keywords: wounds, skin, diabetic, multidrug, mixed infection
\end{abstract}

(c) The Author(s) 2021. Open Access. This article is distributed under the terms of the Creative Commons Attribution 4.0 International License which permits unrestricted use, sharing, distribution, and reproduction in any medium, provided you give appropriate credit to the original author(s) and the source, provide a link to the Creative Commons license, and indicate if changes were made. 


\section{INTRODUCTION}

The skin or under skin tissue (wound) infections could be deep-seated soft tissue infections. These types of infections include the infections of the skin layer (subcutaneous tissue) and muscle tissue layers. Other deeper infections known as cellulitis target the multilayer of the skin $^{1}$.

Multidrug-resistant (MDR) bacteria that cause wound infection cases are considered one of the most dangerous causative agents. The acute burns and wound infections were found to be related to aerobic gram-positive cocci while the chronic wound infections are related to more complex flora. In addition to Pseudomonas aeruginosa, MDR gram-negative bacteria and methicillin-resistant Staphylococcus aureus (MRSA) are the most common isolated infectious agents from complicated infected wounds ${ }^{1-3}$. Recent studies have shown that $20-50 \%$ of diabetic foot infections are due to MRSA ${ }^{4,5}$.

Antimicrobial resistance in MDR bacteria colonized burn wound infections is a major concern
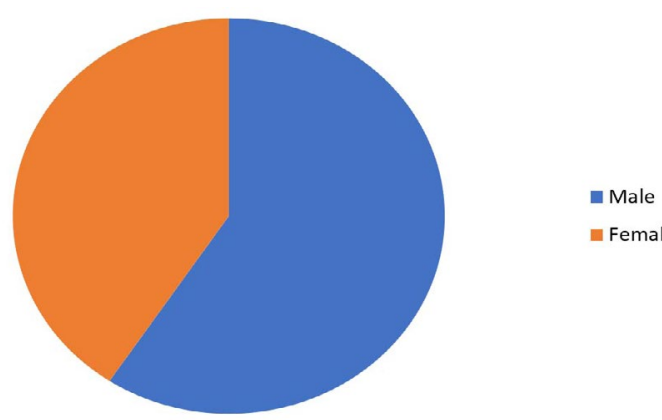

- Female

Fig. 1. Female and male distribution for diabetic foot swab patients in intensive care or burns units worldwide ${ }^{6}$. This has resulted in a great threat to efforts against bacterial pathogens ${ }^{7}$. The aim of this study is to determine the rate of antibiotic-resistant bacterial isolates from wound patients at Islamic hospitals, Amman, Jordan.

\section{MATERIALS AND METHODS}

Study design

This study was conducted at Islamic hospitals in Amman, Jordan from January 1 to November 11, 2018. In and outpatients from surgery and admitted wards were involved in this study. All the patients who fulfilled the criteria above were consecutively enrolled into the study. Sampling and processing

Clinical samples from 607 wound infected patients, including wound swabs 331 (54.4\%), pus $128(21.1 \%)$, and diabetic foot swabs 148 (24.4\%) were aseptically collected using the appropriate sterile containers. The collected samples were transported to the lab with the appropriate transport media and bacterial

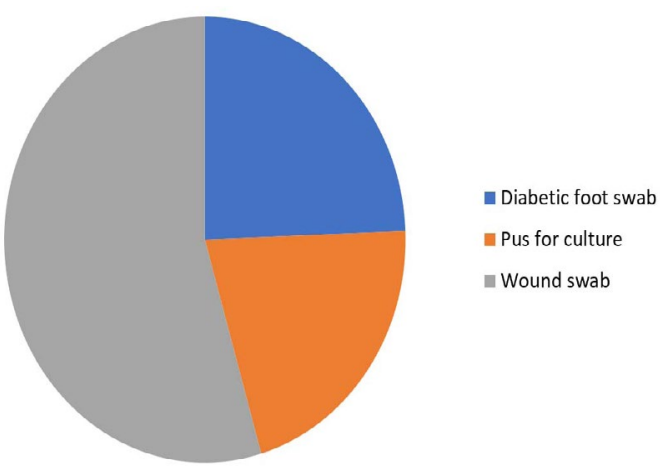

Fig. 2. Study population

Table 1. Characteristics of the study population

\begin{tabular}{|c|c|c|c|}
\hline \multicolumn{3}{|l|}{ A- Gender distributions (males and females) } & \multirow[b]{2}{*}{ Total } \\
\hline Type of culture & Male & Female & \\
\hline Numbers of patients for wound swab & 207 & 124 & 331 \\
\hline Percentage of patients for wound swab & $63 \%$ & $37 \%$ & \\
\hline Numbers of patients for diabetic foot swab & 65 & 83 & 148 \\
\hline Percentage of patients for diabetic foot swab & $44 \%$ & $56 \%$ & \\
\hline Numbers of patients for pus for culture & 88 & 40 & 128 \\
\hline Percentage of patients for pus for culture & $69 \%$ & $31 \%$ & \\
\hline Total number & 360 & 247 & 607 \\
\hline Total percentage & $59 \%$ & $41 \%$ & $100 \%$ \\
\hline
\end{tabular}


identification to species level was performed using standard procedures including culture and colony characteristics, Gram reaction, and different biochemical analysis.

\section{Antibiotic sensitivity test}

The antibacterial susceptibility testing was performed using the modified Kirby-Bauer method. Discs of the following antimicrobials were used: ceftriaxone $(30 \mu \mathrm{g})$, ceftizoxime $(30 \mu \mathrm{g})$, cefoxitin $(30 \mu \mathrm{g})$, gentamicin $(10 \mu \mathrm{g})$, amoxicillin/clavulanate $(30 \mu \mathrm{g})$, cefuroxime (30 $\mu \mathrm{g})$, nitrofurantoin $(100 \mu \mathrm{g})$, ceftazidime $(30 \mu \mathrm{g})$, ciprofloxacin $(10 \mu \mathrm{g})$, ofloxacin $(10 \mu \mathrm{g})$, pefloxacin $(30 \mu \mathrm{g})$, clindamycin $(2 \mu \mathrm{g})$, ampicillin/sulbactam $(10 / 10 \mu \mathrm{g})$, imipenem $(10 \mu \mathrm{g})$, meropenem(10 $\mu \mathrm{g})$, ertapenem $(10 \mu \mathrm{g})$, clarithromycin $(10 \mu \mathrm{g})$, ampicillin $(30 \mu \mathrm{g})$, Erythromycin $(10 \mu \mathrm{g})$, ampicillin/

Table 2. Types of patients and cultures

\begin{tabular}{lcc}
\hline Types of test & $\begin{array}{c}\text { Number of } \\
\text { tests }\end{array}$ & $\begin{array}{c}\text { Percentage of } \\
\text { total subjects }\end{array}$ \\
\hline Diabetic foot swab & 148 & $24.4 \%$ \\
Pus for culture & 128 & $21.1 \%$ \\
Wound swab & 331 & $54.5 \%$ \\
Total & 607 & $100.0 \%$ \\
\hline
\end{tabular}

Table 3-A. Growth statistics - Number of growth and non-growth samples of the study population

\begin{tabular}{lcc}
\hline Type of sample & $\begin{array}{c}\text { Number of } \\
\text { samples }\end{array}$ & $\begin{array}{c}\text { Percentage of } \\
\text { total subjects }\end{array}$ \\
\hline $\begin{array}{l}\text { Number of growth } \\
\text { samples }\end{array}$ & 510 & $84.0 \%$ \\
$\begin{array}{l}\text { Number of non-growth } \\
\text { samples } \\
\text { Total }\end{array}$ & 97 & $16.0 \%$ \\
& 607 & $100.0 \%$
\end{tabular}

Table 3-C. Growth statistics - Number of growth and non-growth diabetic foot ulcer samples

\begin{tabular}{lcc}
\hline Type of sample & $\begin{array}{c}\text { Number of } \\
\text { samples }\end{array}$ & $\begin{array}{c}\text { Percentage of } \\
\text { total subjects }\end{array}$ \\
\hline $\begin{array}{l}\text { Number of growth } \\
\text { samples }\end{array}$ & 130 & $87.8 \%$ \\
$\begin{array}{l}\text { Number of non-growth } \\
\text { samples } \\
\text { Total }\end{array}$ & 18 & $12.2 \%$ \\
\hline
\end{tabular}

cloxacillin $(30 \mu \mathrm{g})$, cefixime $(5 \mu \mathrm{g})$, levofloxacin (10 $\mu \mathrm{g})$, norfloxacin $(10 \mu \mathrm{g})$, and metronidazole $(5 \mu \mathrm{g})$. Ethics

Ethical approval was obtained from the Health Research Ethics Committee of the Ministry of Health.

\section{Data analysis}

Data analysis was performed using Statistical Package for the Social Sciences (SPSS) version 23 (IBM Corp, 2015). Qualitative data were described as proportions or percentages; cross tabulation was used where necessary. Test of significance for differences for quantitative and categorical variables were performed using the $t$-test and Chi square test, respectively. A p-value of $<0.05$ was considered significant.

\section{RESULTS}

\section{General characteristics}

The total number of patients enrolled in this study was $607 ; 331$ of them were wound infected patients, which forms $54.4 \%$ of the total population. Of these, females were 124 (63\%) and males were 207 (37\%). The patients with diabetic foot ulceration (DFU) were 148, which forms $24.4 \%$ of the total population. Among them, 83 (56\%) were female patients and 65 (44\%) were

Table 3-B. Growth statistics - Number of growth and non-growth wound samples

\begin{tabular}{lcc}
\hline Type of sample & $\begin{array}{c}\text { Number of } \\
\text { samples }\end{array}$ & $\begin{array}{c}\text { Percentage of } \\
\text { total subjects }\end{array}$ \\
\hline $\begin{array}{l}\text { Number of growth } \\
\text { samples }\end{array}$ & 282 & $85.2 \%$ \\
$\begin{array}{l}\text { Number of non-growth } \\
\text { samples } \\
\text { Total }\end{array}$ & 49 & $14.8 \%$ \\
& 331 & $100.0 \%$
\end{tabular}

Table 3-D. Growth statistics - Number of growth and non-growth pus samples

\begin{tabular}{lcc}
\hline Type of sample & $\begin{array}{c}\text { Number of } \\
\text { samples }\end{array}$ & $\begin{array}{c}\text { Percentage of } \\
\text { total subjects }\end{array}$ \\
\hline $\begin{array}{l}\text { Number of growth } \\
\text { samples }\end{array}$ & 98 & $76.6 \%$ \\
$\begin{array}{l}\text { Number of non-growth } \\
\text { samples } \\
\text { Total }\end{array}$ & 30 & $23.4 \%$ \\
\hline 50 & 128 & $100.0 \%$ \\
\hline
\end{tabular}


male patients. The glycemic control for the DFU group was generally poor: $10.5 \%$ and more. The pus culture patients were 128 , which forms $21.1 \%$ of the total population; female patients were $40(31 \%)$ and males were $88(69 \%)$. The overall percentage of females over males is $41 / 59$ (Table $1 \&$ Table 2).

Out of the 607 total samples, $510(84.0 \%)$ samples showed growth. Among wound samples, growth cultures were observed in 282 samples (85.2\%) while the non-growth samples were 49

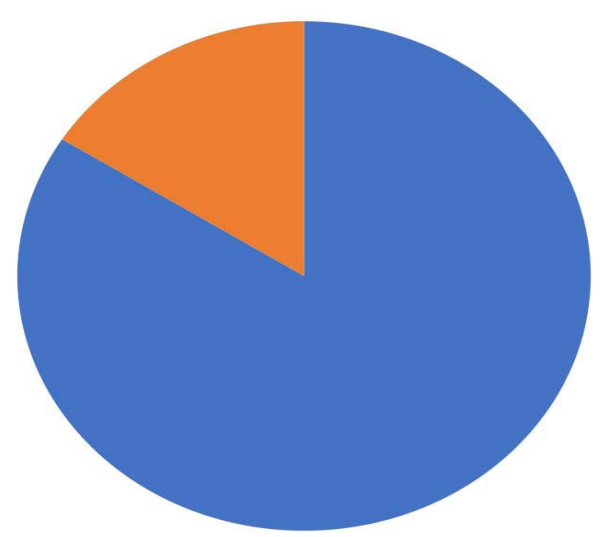

Fig. 3. Study population for growth and non-growth.

\section{Bacterial profile and patterns of infections for wounds cultures}
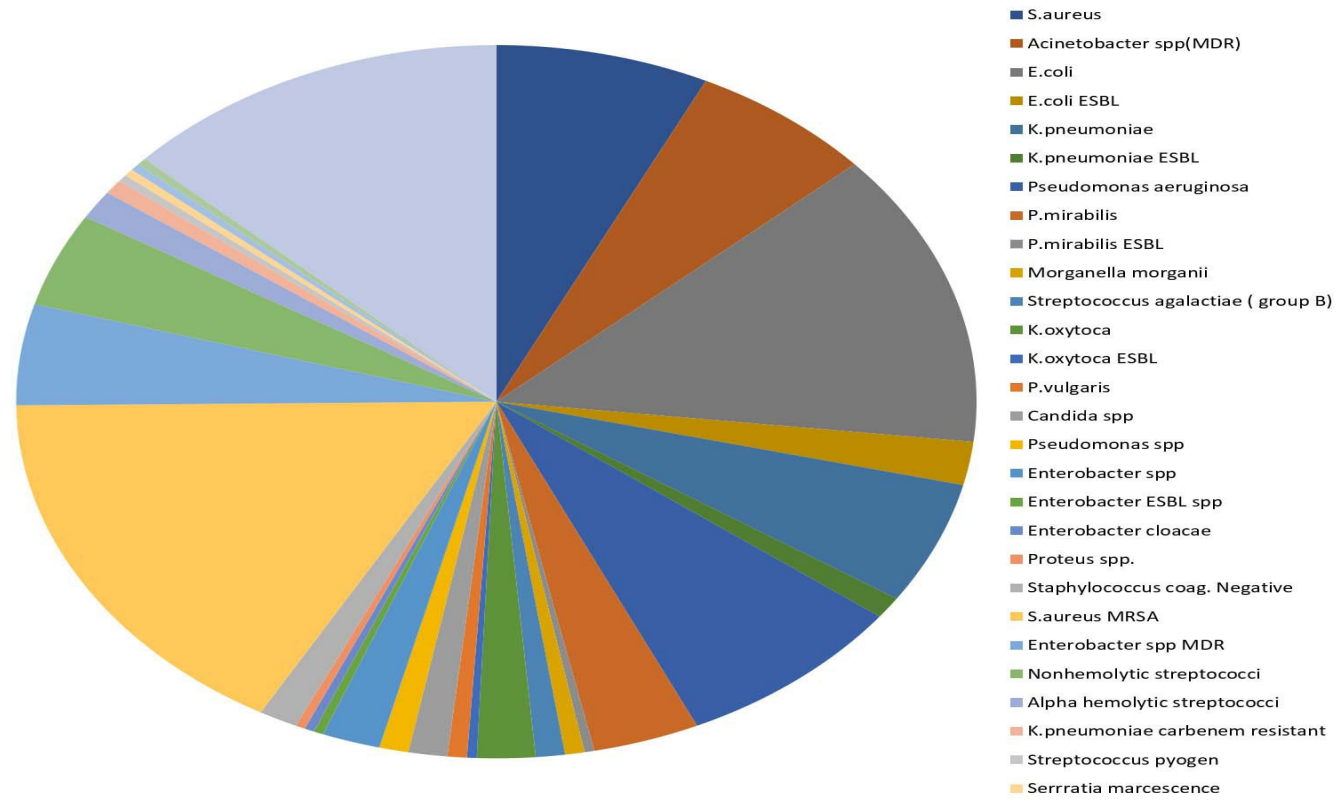

Fig. 4. Bacterial profile and patterns of infection for wounds cultures. 
Enterobacter spp MDR, and nonhemolytic Streptococcus spp. (Table 4-A.1), Descriptive tables (Appendix: Supplementary tables) and Fig. 4.

More than $30 \%$ of wound infections were resistant to the antibiotics. The most frequent high resistant isolates in wound infections were; MRSA, Acinetobacter spp. (MDR), Enterobacter spp. MDR, E. coli ESBL, K. pneumoniae ESBL, K. pneumoniae carbapenem-resistant, P. mirabilis ESBL, K. oxytoca

\title{
High resistant drug isolates of wound infection
}

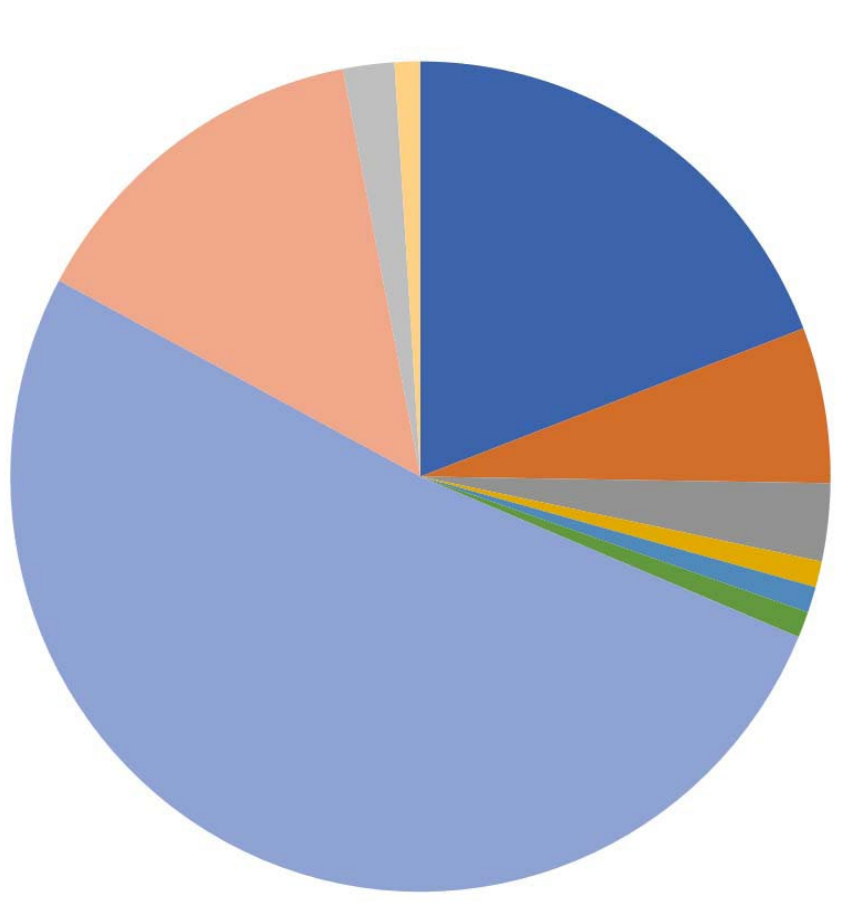

\author{
Acinetobacter \\ $\operatorname{spp}(\mathrm{MDR})$ \\ E.coli ESBL \\ K.pneumoniae \\ ESBL \\ - P.mirabilis ESBL \\ K.oxytoca ESBL \\ - Enterobacter \\ ESBL spp \\ - S.aureus MRSA \\ Enterobacter spp \\ MDR \\ K.pneumoniae \\ carbenem \\ resistant
}

Fig. 5. High drug-resistant isolates of wound infections.

\section{Multidrug resistant isolates of wound culture}

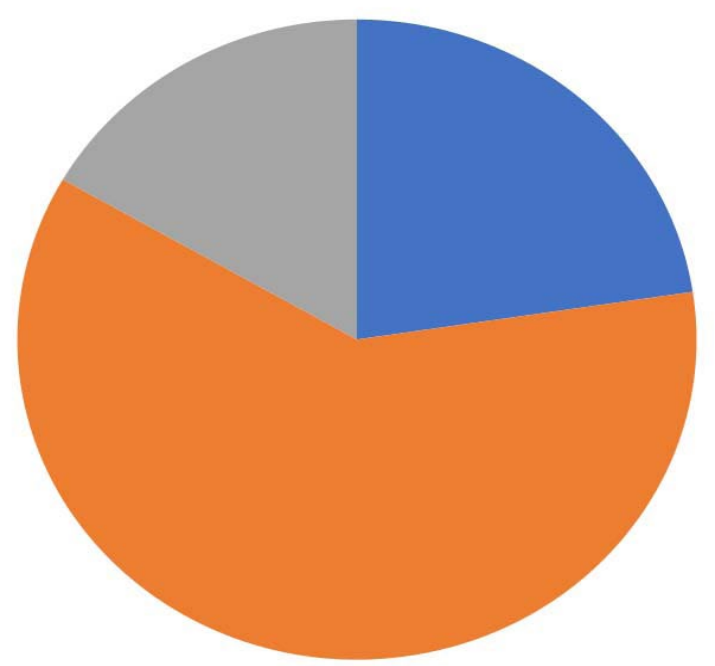

- Acinetobacter spp(MDR)

- S.aureus MRSA

Enterobacter spp MDR

Fig. 6. Multidrug resistant isolates of wound culture 
ESBL, Enterobacter spp. ESBL, VRE (see Table 4-A.2) and Fig. 5.

The result shows $27.5 \%$ of the infections were MDR infections. MRSA was the most aggressive pathogen among the multidrugresistant isolates (MDR) for wound cultures, which formed more than $51 \%$ of MDR agents, followed by Acinetobacter spp. (MDR), and then by Enterobacter spp MDR (Table4-A.3) and Fig. 6. In diabetic foot ulcer swabs, 17 pathogens were isolated. One yeast and 16 types of bacteria.
S. aureus was the most frequent pathogen followed by $E$. coli, Acinetobacter spp. (MDR), $K$. pneumoniae, $P$. aeruginosa, and $P$. mirabilis. Enterobacter spp. ESBL, CoNS, and Streptococcus viridans were the less frequent pathogens. Candida spp. were recorded as one of the causes of infection in two cases. Nineteen patients had no pathogenic microbes (Table 4-B.1) and Fig. 7.

The most drug-resistant isolates of diabetic foot ulcers were MRSA, followed by Acinetobacter spp. (MDR), P. mirabilis ESBL,
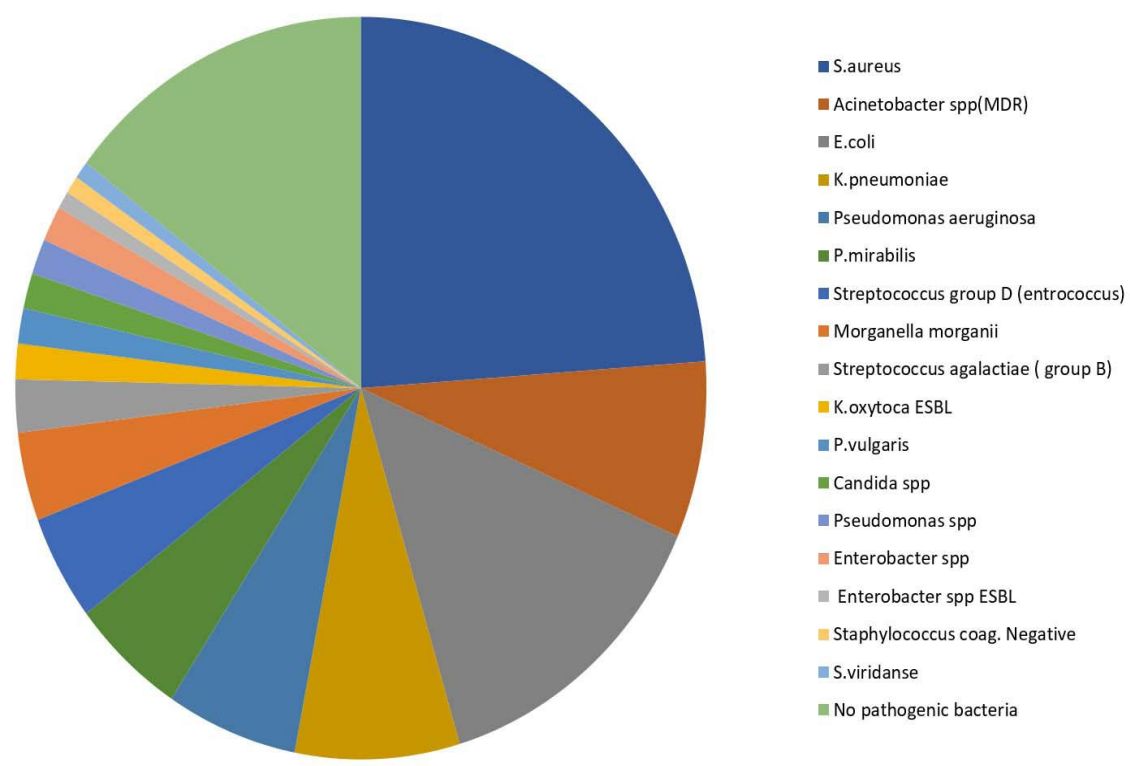

Fig. 7. Diabetic foot ulcer infections

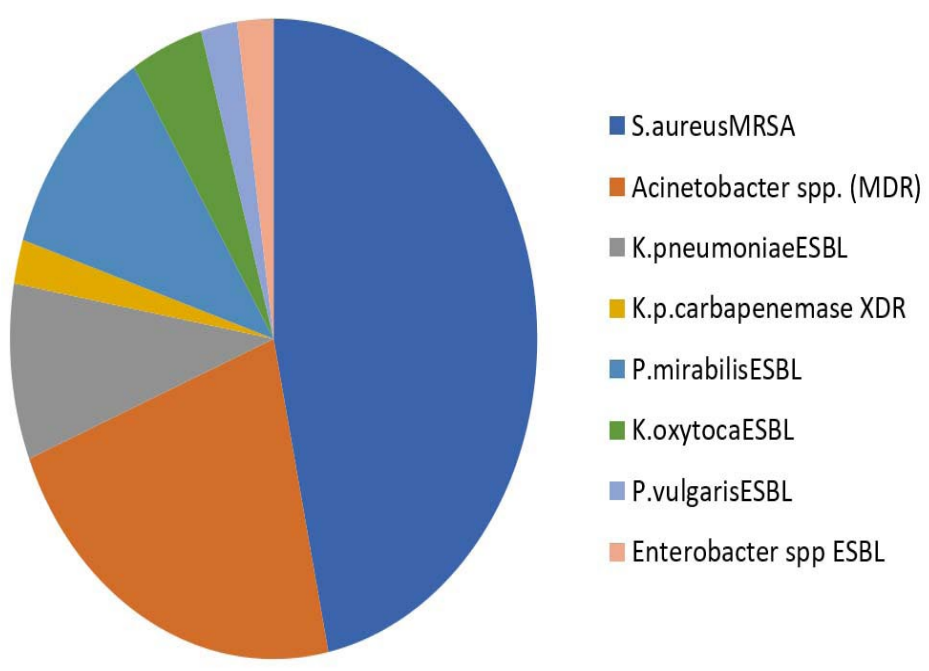

Fig. 8. High drug-resistant isolates of diabetic foot ulcers 
K. pneumoniae ESBL, K. oxytoca ESBL, and $K$. pneumoniae carbapenemase XDR (see Table 4-B.2) and Fig. 8.

A quarter and more of infections in diabetic foot ulcers are caused by multidrug resistant bacteria; MRSA (16.2\%) was the most frequent pathogen among these pathogens, followed by Acinetobacter spp. (MDR) (7.7\%), K. pneumonia carbapenemase XDR (0.8\%), and Enterobacter spp. ESBL (0.8\%) (Table 4-B.2) and Fig. 8.

For the pus samples, 19 pathogens were isolated. E. coli (21.4\%) was the most frequent pathogen, followed by S. aureus (14.0\%), and S. aureus (MDR) (11.0\%), nonhemolytic

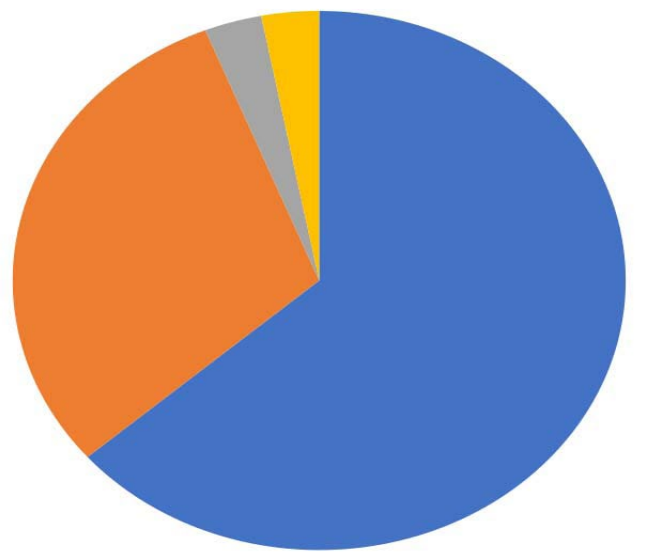

S. aureus MRSA

Acinetobacter spp. (MDR)

K.p.carbapenemase XDR

Enterobacter spp ESBL

Fig. 9. Multidrug resistant isolates of diabetic foot ulcers

\section{Infections of pus samples}
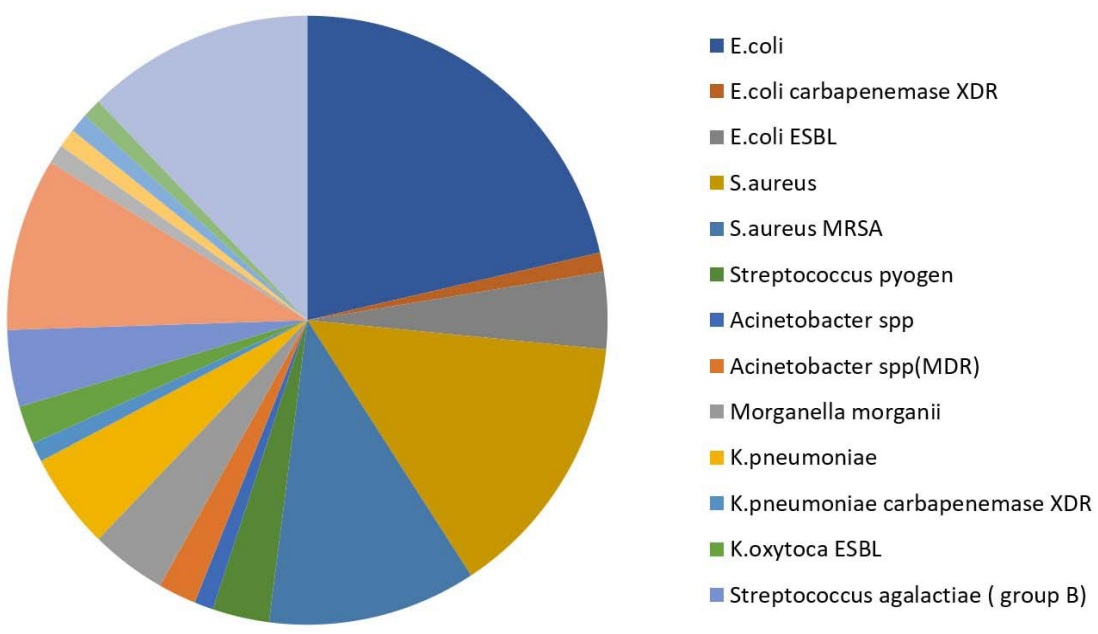

Fig. 10. Pathogenic agents of the pus samples 


\section{High drug resistant and MDR for pus samples}

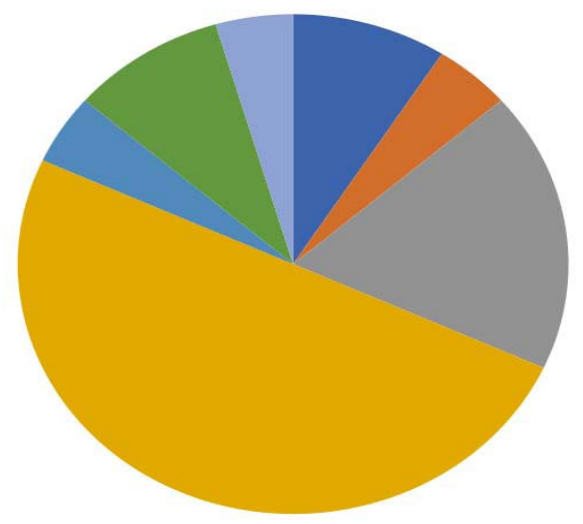

- Acinetobacter spp(MDR)

E.coli carbapenemase XDR

E.coli ESBL

S.aureus MRSA

Vancomycin resitant enterococcus

Fig. 11. High drug resistant and MDR isolates of the pus samples

\section{Multidrug resistant isolates of for pus}

\section{samples}

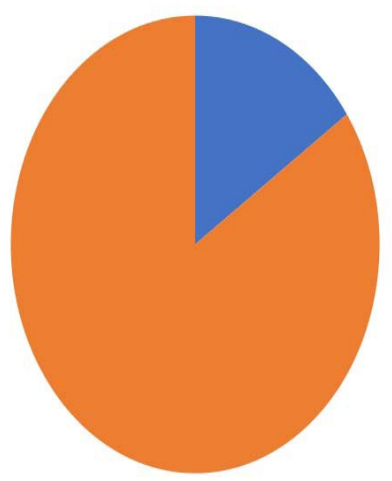

Acinetobacter spp(MDR)

S. aureus MRSA

Fig. 12. Multidrug-resistant isolates of the pus samples

Types of pathogens for the mixed infections of wound infections
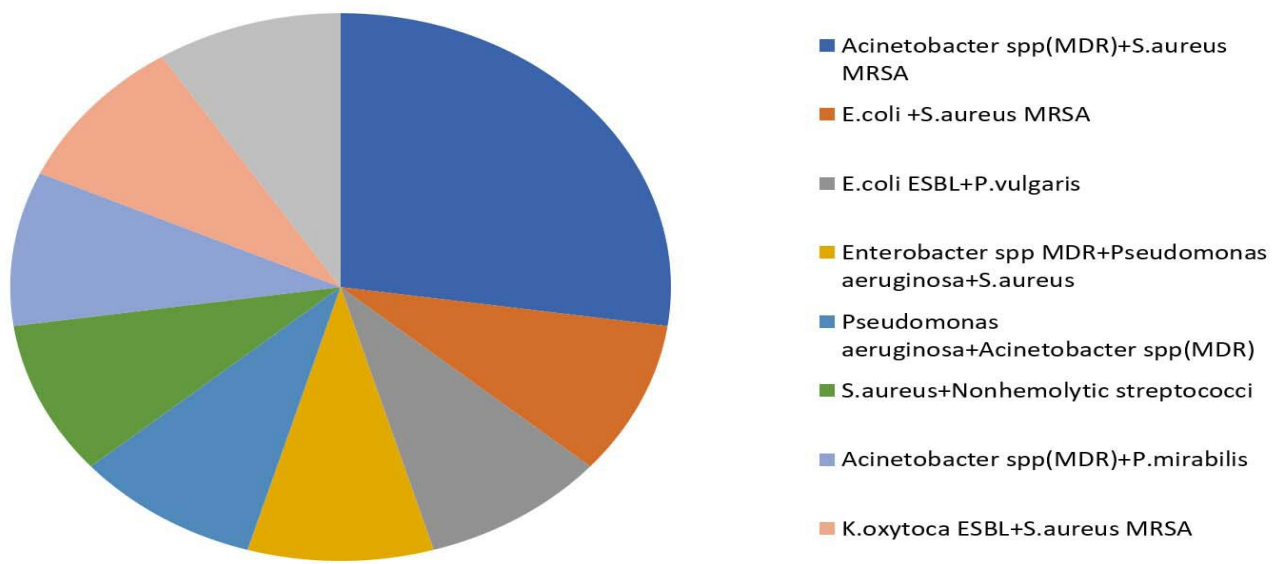

- Acinetobacter spp(MDR)+S.aureus MRSA

E.coli +S.aureus MRSA

E.coli ESBL+P.vulgaris

Enterobacter spp MDR+Pseudomonas aeruginosa+S.aureus

- Pseudomonas

aeruginosa+Acinetobacter spp(MDR)

S.aureus+Nonhemolytic streptococci

Acinetobacter spp(MDR)+P.mirabilis

K.oxytoca ESBL+S.aureus MRSA

Fig. 13. Types of pathogen combinations for the mixed wound infections 
Only $14.3 \%$ of infections in the pus samples were caused by multidrug resistant bacteria; MRSA (11.2\%) was the main cause of infections and the second cause was Acinetobacter spp. (MDR) (3.1\%) (Table 4-C.3) and Fig. 11.

The result showed that $3.3 \%$ of the wounds were mixed infections caused by more than one bacterium; all of the mixed infections were in diabetic patients (Table 5).

Acinetobacterspp. (MDR) and MRSA were the most frequent combination in mixed infections by percent of $27.3 \%$ of the total infections of wounds, followed by $E$. coli and MRSA, E. coli ESBL and $P$. vulgaris, Enterobacter spp. MDR and $P$. aeruginosa and $S$. aureus, $P$. aeruginosa and Acinetobacter spp. (MDR), S. aureus and nonhemolytic streptococci, Acinetobacter spp. (MDR) and P. mirabilis, K. oxytoca ESBL and MRSA, and MRSA and K. pneumoniae (Table 6) and Fig. 12.

\section{DISCUSSION}

Wound infections are becoming an actual burden of lesions globally. Recently, the World Health Organization reported a catalog of antibiotic-resistant "priority pathogens." In this catalog was a list of 12 families of bacteria that are the greatest threat to human health. At the top of the list was the most important causative pathogen in wound infection MRSA, which is spreading globally and constitutes the cause of approximately $20 \%$ of wound infections. The prevalence of antibiotic-resistant strains of S. aureus is increasing at an alarming rate. The highest resistance was recorded against ampicillin and erythromycin ( $88 \%$ each), while resistances against oxacillin, fosfomycin, cefoxitin, and ciprofloxacin were also worrisome ${ }^{8}$.

In this study, the results showed that MRSA accounted for $16.7 \%$ of total wound infections. E. coli is presented in the list of most common causative agents of wounds, and causes approximately $13.4 \%$ of wound infections in Jordan; $P$. aeruginosa accounts for approximately $8 \%$ of wound infections in Jordan. Acinetobacter spp. (MDR) is the second multidrug-resistant pathogen accounting for $6.2 \%$ of the total infections. The other pathogens form less than 50\%; K. pneumoniae, Enterobacter spp. MDR, and nonhemolytic streptococci. The infectious agents were $E$. coli ESBL, $K$. pneumoniae ESBL, $P$. aeruginosa, $P$. mirabilis, $P$. mirabilis ESBL, M. morganii, S. agalactiae (group B), $K$. oxytoca, K. oxytoca ESBL, P. vulgaris, Candida spp. (yeast), Pseudomonas spp., Enterobacter spp.,

Table 4-A.1. Bacterial profile and patterns of infection for wound infections

\begin{tabular}{|c|c|c|}
\hline Type of pathogen & $\begin{array}{l}\text { Number of } \\
\text { infections }\end{array}$ & Percentage \\
\hline S. aureus & 22 & $7.2 \%$ \\
\hline $\begin{array}{l}\text { Acinetobacter spp. } \\
\text { (MDR) }\end{array}$ & 19 & $6.2 \%$ \\
\hline E. coli & 41 & $13.4 \%$ \\
\hline E. coli ESBL & 6 & $2.0 \%$ \\
\hline K. pneumoniae & 17 & $5.6 \%$ \\
\hline K. pneumoniae ESBL & 3 & $1.0 \%$ \\
\hline P. aeruginosa & 24 & $7.8 \%$ \\
\hline P. mirabilis & 11 & $3.6 \%$ \\
\hline P. mirabilis ESBL & 1 & $0.3 \%$ \\
\hline M. morganii & 2 & $0.7 \%$ \\
\hline S. agalactiae (group B) & 3 & $1.0 \%$ \\
\hline K. oxytoca & 6 & $2.0 \%$ \\
\hline K. oxytoca ESBL & 1 & $0.3 \%$ \\
\hline P. vulgaris & 2 & $0.7 \%$ \\
\hline Candida spp. & 4 & $1.3 \%$ \\
\hline Pseudomonas spp. & 3 & $1.0 \%$ \\
\hline Enterobacter spp. & 6 & $2.0 \%$ \\
\hline Enterobacter spp. ESBL & 1 & $0.3 \%$ \\
\hline E. cloacae & 1 & $0.3 \%$ \\
\hline Proteus spp. & 1 & $0.3 \%$ \\
\hline Coagulase negative & 4 & $1.3 \%$ \\
\hline \multicolumn{3}{|l|}{ Staphylococcus (CoNS) } \\
\hline Methicillin-resistant & 51 & $16.7 \%$ \\
\hline \multicolumn{3}{|l|}{$\begin{array}{l}\text { Staphylococcus aureus } \\
\text { (MRSA) }\end{array}$} \\
\hline Enterobacter spp. MDR & 14 & $4.6 \%$ \\
\hline Nonhemolytic streptococci & 13 & $4.2 \%$ \\
\hline Alpha hemolytic streptococci & 4 & $1.3 \%$ \\
\hline $\begin{array}{l}\text { K. pneumoniae carbapenem } \\
\text { resistant }\end{array}$ & 2 & $0.7 \%$ \\
\hline S. pyogenes & 1 & $0.3 \%$ \\
\hline Serratia marcescens & 1 & $0.3 \%$ \\
\hline Citrobacter freundii & 1 & $0.3 \%$ \\
\hline Vancomycin resistant & 1 & $0.3 \%$ \\
\hline \multicolumn{3}{|l|}{ Enterococcus spp. (VRE) } \\
\hline No pathogenic bacteria & 40 & $13.1 \%$ \\
\hline No growth after $48 \mathrm{~h}$ & 49 & \\
\hline Total & 306 & $100.0 \%$ \\
\hline
\end{tabular}

MDR- multidrug resistant; ESBL- extended spectrum $\beta$-lactamase 
Enterobacter spp. ESBL, Enterobacter cloacae, Proteus spp., CoNS, Alpha hemolytic streptococci, and $K$. pneumoniae carbenem of infections (Table 4-A.1) and Fig. 4. ${ }^{4,9}$.

Infection with MDR gram-negative organisms in most cases leads to poorer outcomes in burns, especially in critical cases. These bacteria

Table 4-A.2. High drug-resistant isolates of wound infections

\begin{tabular}{lcc} 
Type of pathogen & $\begin{array}{c}\text { Number of } \\
\text { infections }\end{array}$ & Percentage \\
\hline Acinetobacter spp (MDR) & 19 & $6.2 \%$ \\
E. coli ESBL & 6 & $2.0 \%$ \\
K. pneumoniae ESBL & 3 & $1.0 \%$ \\
P. mirabilis ESBL & 1 & $0.3 \%$ \\
K. oxytoca ESBL & 1 & $0.3 \%$ \\
Enterobacter ESBL spp & 1 & $0.3 \%$ \\
MRSA & 51 & $16.7 \%$ \\
Enterobacter spp MDR & 14 & $4.6 \%$ \\
K. pneumoniae carbapenem & 2 & $0.7 \%$ \\
resistant & 1 & $0.3 \%$ \\
VRE & 99 & $32.0 \%$ \\
Total & & \\
\hline
\end{tabular}

Table 4-B.1. Diabetic foot ulcer infections

\begin{tabular}{lcc}
\hline Type of pathogen & $\begin{array}{c}\text { Number of } \\
\text { infections }\end{array}$ & Percentage \\
\hline S. aureus & 31 & $23.8 \%$ \\
Acinetobacter spp. (MDR) & 10 & $7.7 \%$ \\
E. coli & 18 & $13.8 \%$ \\
K. pneumonia & 10 & $7.7 \%$ \\
P. aeruginosa & 8 & $6.2 \%$ \\
P. mirabilis & 7 & $5.4 \%$ \\
Streptococcus group D & 6 & $4.6 \%$ \\
(Enterococcus) & & \\
M. morganii & 5 & $3.8 \%$ \\
S. agalactiae ( group B) & 3 & $2.3 \%$ \\
K. oxytoca ESBL & 2 & $1.5 \%$ \\
P. vulgaris & 2 & $1.5 \%$ \\
Candida spp. & 2 & $1.5 \%$ \\
Pseudomonas spp & 2 & $1.5 \%$ \\
Enterobacter spp & 2 & $1.5 \%$ \\
Enterobacter spp ESBL & 1 & $0.8 \%$ \\
CoNS & 1 & $0.8 \%$ \\
S. viridanse & 1 & $0.8 \%$ \\
No pathogenic bacteria & 19 & $14.6 \%$ \\
Total number & 130 & $100.0 \%$ \\
\hline
\end{tabular}

and the future horror of multidrug-resistance (MDR), the challenge among Jordanian healthcare providers, and the patients suffering from complications demonstrate the actual burden of infections and the progression of the infections cause the causative bacteria to be highly resistant to wound infections. This study showed that approximately $67 \%$ of the infections are caused by gram-negative bacteria while approximately

Table 4-A.3. Multidrug-resistant isolates of wound culture

\begin{tabular}{lcc}
\hline Type of pathogen & $\begin{array}{c}\text { Number of } \\
\text { infections }\end{array}$ & Percentage \\
\hline Acinetobacter spp(MDR) & 19 & $6.2 \%$ \\
MRSA & 51 & $16.7 \%$ \\
Enterobacter spp MDR & 14 & $4.6 \%$ \\
Total number & 84 & $27.5 \%$ \\
\hline
\end{tabular}

Table 4-B.2. High drug-resistant and MDR isolates of foot ulcer infections

\begin{tabular}{lcc}
\hline Type of pathogen & $\begin{array}{c}\text { Number of } \\
\text { infections }\end{array}$ & Percentage \\
\hline MRSA & 21 & $16.2 \%$ \\
Acinetobacter spp. (MDR) & 10 & $7.7 \%$ \\
K. pneumoniae ESBL & 4 & $3.1 \%$ \\
K. pneumonia & 1 & $0.8 \%$ \\
carbapenemase XDR & & \\
$P$. mirabilis ESBL & 5 & $3.8 \%$ \\
K. oxytoca ESBL & 2 & $1.5 \%$ \\
$P$. vulgaris ESBL & 1 & $0.8 \%$ \\
Enterobacter spp. ESBL & 1 & $0.8 \%$ \\
Total number & 53 & $40.8 \%$ \\
Total number & 98 & $42.3 \%$ \\
\hline
\end{tabular}

Table 4-B.3. Multidrug-resistant isolates of diabetic foot ulcers

\begin{tabular}{lcc}
\hline Type of pathogen & $\begin{array}{c}\text { Number of } \\
\text { infections }\end{array}$ & $\begin{array}{c}\text { Percentage of } \\
\text { diabetic foot } \\
\text { swabinfections }\end{array}$ \\
\hline MRSA & 21 & $16.2 \%$ \\
Acinetobacter spp. (MDR) & 10 & $7.7 \%$ \\
K. pneumonia & 1 & $0.8 \%$ \\
Enterobacter spp. ESBL & 1 & $0.8 \%$ \\
Total number & 33 & $25.4 \%$ \\
\hline
\end{tabular}


$32 \%$ are caused by gram-positive bacteria, which is within the global ratios ${ }^{9,10}$.

The highly significant $(p<0.001)$ MDR results are drawing attention to focusing more on handling and taking care of the management and treatment of wounds in Jordan. The risk of developing high drug-resistant isolates of wound was high, approximately $32 \%$ of the total infections. The new types of bacteria, especially E. coli ESBL, K. pneumoniae ESBL, K. pneumoniae carbenem resistant, $P$. mirabilis ESBL, $K$. oxytoca ESBL, Enterobacter ESBL spp., and VRE, constituted $8.8 \%$ while the actual MDR constituted $23.2 \%$ (see Table 4-A.2) and Fig. $5^{10}$.

The high cost and lack of well-trained multidisciplinary medical personnel, facilities, and standardized management protocols are possible contributory factors. Physicians also have an important role in the prevention, early diagnosis, and management of infections of wounds with multidrug resistant or high resistant microbes for chemotherapies. MDR isolates of foot ulcers were reported though the patients reported that the ulcers resulted from spontaneous blisters or physicians reported the ulcers as wounds. There is a small percentage of overlap between diabetic foot ulcers and diabetic wounds, therefore, there is a possibility that some of the ulcers may have resulted from unnoticed micro-trauma. Inappropriate footwear might lead to spontaneous blisters; this was found to be the second commonest predisposing event for DFU. In addition, fitting of footwears in patients with peripheral neuropathy may result in foot ulcerations in patients with insensate feet. The use of disordered machines or tools and abnormal weight-bearing in peripheral areas of the foot in patients with peripheral neuropathy could make the foot susceptible to ulceration while wearing shoes.

Self-inflicted burns due to thermal injury resulting from the application of hot compresses to numb feet precipitated two cases of DFU. This might cause ulcerations and wounds or burns and should be taken care of in foot ulceration studies ${ }^{11}$.

Table 4-C.2. High drug-resistant and MDR isolates of the pus samples

\begin{tabular}{lcc}
\hline Type of pathogen & $\begin{array}{c}\text { Number of } \\
\text { infections }\end{array}$ & Percentage \\
\hline Acinetobacter spp. (MDR) & 2 & $2.0 \%$ \\
E. coli carbapenemase XDR & 1 & $1.0 \%$ \\
E. coli ESBL & 4 & $4.1 \%$ \\
MRSA & 11 & $11.2 \%$ \\
VRE & 1 & $1.0 \%$ \\
K. oxytoca ESBL & 2 & $2.0 \%$ \\
K. pneumoniae & 1 & $1.0 \%$ \\
carbapenemase XDR & & \\
Total number & 22 & $22.4 \%$ \\
\hline
\end{tabular}

Table 4-C.3. Multidrug-resistant isolates of the pus samples

$4.1 \%$

$9.2 \%$

$1.0 \%$

$1.0 \%$

$1.0 \%$

$1.0 \%$

$12.2 \%$

No pathogenic bacteria

No growth after $48 \mathrm{~h}$

$52.0 \%$

\begin{tabular}{lcc}
\hline Type of pathogen & $\begin{array}{c}\text { Number of } \\
\text { infections }\end{array}$ & Percentage \\
\hline Acinetobacter spp. (MDR) & 3 & $3.1 \%$ \\
MRSA & 11 & $11.2 \%$ \\
Total number & 14 & $14.3 \%$ \\
\hline
\end{tabular}


Table 5. Percentage of mixed wound infections

\begin{tabular}{lcc}
\hline $\begin{array}{l}\text { Number of } \\
\text { mixed infections }\end{array}$ & $\begin{array}{l}\text { Percentage of mixed } \\
\text { wound infections }\end{array}$ & Note \\
\hline 11 & $3.3 \%$ & $\begin{array}{c}\text { All were } \\
\text { diabeticpatients }\end{array}$
\end{tabular}

Thus, there is a need to ensure that better-focused education and the determination of the best way to handle and take care of ulcer foot cases on appropriate footwear, foot care, and other harmful practices be intensified among these patients.

Table 6. Types of pathogen combinations for the mixed wound infections

\begin{tabular}{lcc}
\hline Type of pathogen combinations & $\begin{array}{c}\text { Number of } \\
\text { infections }\end{array}$ & Percentage \\
\hline Acinetobacter spp. (MDR) + MRSA & 3 & $27.3 \%$ \\
E. coli + MRSA & 1 & $9.1 \%$ \\
E. coli ESBL + P. vulgaris & 1 & $9.1 \%$ \\
Enterobacter spp. MDR + P. aeruginosa + S. aureus & 1 & $9.1 \%$ \\
P. aeruginosa + Acinetobacter spp. (MDR) & 1 & $9.1 \%$ \\
S. aureus + Nonhemolytic streptococci & 1 & $9.1 \%$ \\
Acinetobacter spp. (MDR) + P. mirabilis & 1 & $9.1 \%$ \\
K. oxytoca ESBL + MRSA & 1 & $9.1 \%$ \\
MRSA + K. pneumonia & 1 & $9.1 \%$ \\
Total number & 11 & $100.0 \%$ \\
\hline
\end{tabular}

\section{The bacteriological pattern of diabetic foot ulcers}

In the present study, a total of 17 different microorganisms were isolated from the participants, with mixed gram-positive and gramnegative species and the yeast Candida albicans; an average of 1:4 gram-positive aerobic bacteria, 4:1 gram-negative aerobic bacteria, and $1: 16$ yeast gave an overall average of $0.13 \%$ (6.7) organisms per case. This is similar to the findings of a study in the USA, which had a larger sample size ${ }^{12}$.

The predominance of gram-negative aerobes has also been reported by field workers and previous studies ${ }^{13}$. These differences could be partly due to changes in the causative organisms occurring over time, and the capability of microbes to develop more resistance to antibiotics. It might also be affected by geographical variations or the types and severity of the infection. The differences in results might be due to the use of a "relatively small number of specimens", and limited specimen collection techniques, which would fail to exclude superficial or colonizing organisms, poor handling techniques, and poor preservation methods, which might affect the cultivation of anaerobic organisms $^{14,15}$.

The bacteriological pattern of pus sample isolates In the present study, a total of 18 different microorganisms were isolated from the participants, most of them (85.7\%) were neither multi-resistant nor high resistant bacteria to antibiotics; E. coli (21.4\%) was the most frequent pathogen followed by $S$. aureus (not multi-resistant) (14\%), S. aureus (MDR) (11\%), nonhemolytic streptococci (9\%), and then the others; K. pneumoniae, S. agalactiae (group B), $M$. morganii, E. coli ESBL, S. pyogenes, $K$. oxytoca ESBL, Acinetobacter spp. (MDR), VRE, $P$. aeruginosa, $P$. mirabilis, $K$. pneumoniae carbapenemase XDR, E. coli carbapenemase XDR, Alpha hemolytic streptococci, and Acinetobacter spp. constitute approximately $30 \%$ of the total infections. This is consistent with the global results with mixed grampositive and gram-negative species; an average of 1:3 (7/18) gram-positive aerobic bacteria with approximately $44 \%$ of the total infections. (Table 4-C.1) and Fig. 9. ${ }^{16}$.

The multidrug resistant bacteria in pus isolates represented $14.3 \%$ of all the infections and the main causative agents were Acinetobacter spp. (MDR), which is prevalent in Jordan as the cause of nosocomial infections. This explains its predominance in pus and chronic infections than MRSA, which is one of the main causes of wound infection worldwide (Table 4-C.3) and Fig. 11., 1,2,12,17. 
Fifty-four (8.9\%) patients from the study were diabetic, $11(20 \%)$ of them had mixed infections with $3.3 \%$ being wound infections (Table 5).

Most $(27.3 \%)$ of the cases of mixed infections were caused by Acinetobacter spp. (MDR) and MRSA, which may be due to hospitalacquired infections and/or the aggressiveness of these bacteria. Mixed infections by more than two microbes were very rare; only one such case was reported in the present study with three mixed causative agents; Enterobacter spp. MDR, $P$. aeruginosa, and S. aureus. This is an indication of the low chance of multibacterial infections by more than two organisms (Table 6) and Fig. 12.

\section{CONCLUSION}

The global burden from multidrug resistant bacteria affects wound infections, either in hospital-acquired infections or communityacquired infections. The main causative agents of wound infections are MRSA, E. coli, P. aeruginosa, and Acinetobacter spp. (MDR). Gram-negative bacteria caused more than $67 \%$ of the infections compared with gram-positive bacteria. Diabetic patients have more predisposition to mixed infections than the non-diabetic patients.

\section{SUPPLEMENTARY INFORMATION}

Supplementary information accompanies this article at https://doi.org/10.22207/JPAM.15.3.25

Additional file: Additional Table.

\section{ACKNOWLEDGMENTS}

We would like to thank the entire microbiology department and medical directory in Islamic hospital, Jordan for the collaboration during the recruitment process and provided surveillance data.

\section{CONFLICT OF INTEREST}

The authors declare that there is no conflict of interest.

\section{AUTHORS' CONTRIBUTION}

All authors listed have made a substantial, direct and intellectual contribution to the work, and approved it for publication.

\section{FUNDING}

This work was supported by the Deanship of Research in Zarqa University /Jordan"(Grant number 2000\$).

\section{DATA AVAILABILITY}

All datasets generated or analyzed during this study are included in the manuscript.

\section{ETHICS STATEMENT}

This study was carried out in accordance with the recommendations of WHO ethical comity . The protocol was approved by the $\mathrm{MOH}$ Scientific Ethical Comity under the protocol number code\#MOH REC150029.

\section{REFERENCES}

1. Boluki E, Kazemian $\mathrm{H}$, Peeridogaheh $\mathrm{H}$, et al. Antimicrobial activity of photodynamic therapy in combination with colistin against a pan-drug resistant Acinetobacter baumannii isolated from burn patient. Photodiagnosis Photodyn Ther. 2017;18:1-5. doi: 10.1016/j.pdpdt.2017.01.003

2. Sharahi JY, Ahovan ZA, Maleki DT, et al. In vitro antibacterial activity of curcumin-meropenem combination against extensively drug-resistant (XDR) bacteria isolated from burn wound infections. Avicenna J Phytomedicine. 2020;10(1):3-10.

3. Decraene $\mathrm{V}$, Ghebrehewet $\mathrm{S}$, Dardamissis $\mathrm{E}$, et al. An outbreak of multidrug-resistant Pseudomonas aeruginosa in a burns service in the North of England: challenges of infection prevention and control in a complex setting. J Hosp Infect. 2018;100(4):e239-e245. doi: 10.1016/j.jhin.2018.07.012

4. Vinaik R, Barayan D, Shahrokhi S, Jeschke MG. Management and prevention of drug resistant infections in burn patients. Expert Rev Anti Infect Ther. 2019;17(8):607-619. doi: 10.1080/14787210.2019.1648208

5. Sahib A, Abbas S, Hasson K, Mahmoud M. Experience of Antibiotic Use and Resistance Among Pharmacy Students in the University of Kerbala. J Basic Appl Res Biomed. 2019;5(1):21-30.

6. Ranjbar R, Farahani A. Study of genetic diversity, biofilm formation, and detection of Carbapenemase, $M B L, E S B L$, and tetracycline resistance genes in multidrug-resistant Acinetobacter baumannii isolated from burn wound infections in Iran. Antimicrob Resist Infect Control. 2019;8(1):172. doi: 10.1186/s13756019-0612-5

7. Al Fraijat B, Al-Tawarah NM, Khlaifat AM, et al. Urinary tract infection and non-ruptured acute appendicitis association: Uro-pathogens findings. Trop Biomed. 
2019;36(3):620-629.

8. Hanif $E$, Hassan SA. Evaluation of antibiotic resistance pattern in clinical isolates of Staphylococcus aureus. Pak J Pharm Sci. 2019;32(4 (Supplementary)):1749-1753.

9. Vickers ML, Dulhunty JM, Ballard E, et al. Risk factors for multidrug-resistant Gram-negative infection in burn patients. ANZ J Surg. 2018;88(5):480-485. doi: 10.1111/ans.14144

10. Grant SS, Hung DT. Persistent bacterial infections, antibiotic tolerance, and the oxidative stress response. Virulence. 2013;4(4):273-283. doi: 10.4161/viru.23987

11. Anyim O, Okafor C, Young E, Obumneme-Anyim I, Nwatu C. Pattern and microbiological characteristics of diabetic foot ulcers in a Nigerian tertiary hospital. Afr Health Sci. 2019;19(1):1617-1627. doi: 10.4314/ ahs.v19i1.37

12. Hobizal KB, Wukich DK. Diabetic foot infections: current concept review. Diabet Foot Ankle. 2012;3(1):18409. doi: 10.3402/dfa.v3i0.18409

13. Zubair M, Malik A, Ahmad J. Clinico-bacteriology and risk factors for the diabetic foot infection with multidrug resistant microorganisms in north India. Biol Med. 2010;2(4):22-34.

14. Shankar EM, Mohan V, Premalatha G, Srinivasan RS, Usha AR. Bacterial etiology of diabetic foot infections in South India. Eur J Intern Med. 2005;16(8):567-570. doi: 10.1016/j.ejim.2005.06.016

15. Gadepalli R, Dhawan B, Sreenivas V, Kapil A, Ammini AC, Chaudhry R. A clinico-microbiological study of diabetic foot ulcers in an Indian tertiary care hospital. Diabetes Care. 2006;29(8):1727-1732. doi: 10.2337/ dc06-0116

16. Dorau B, Arango R, Green F. An investigation into the potential of ionic silver as a wood preservative. Proceedings from the Woodframe Housing Durability and Disaster Issues Conference: October 4-6, 2004... Las Vegas, Nevada, USA. Madison, WI: Forest Products Society, 2004:133-145.

17. Kujath $\mathrm{P}$, Kujath C. Complicated skin, skin structure and soft tissue infections-are we threatened by multiresistant pathogens? Eur J Med Res. 2010;15(12):544553. doi: 10.1186/2047-783X-15-12-544 